\title{
Analisis Kinerja Pemasaran UMKM Produk Olahan Singkong di Wilayah Lebak-Banten
}

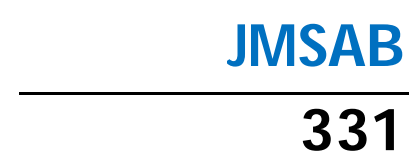

\author{
Research Paper \\ Management
}

Miguna Astuti*, Tati Handayani

Fakultas Ekonomi dan Bisnis, Universitas Pembangunan

Nasional Veteran Jakarta

\begin{abstract}
The purpose of this research To realize economic and social resilience, which is oriented towards poverty alleviation in the context of community welfare in the Lebak Regency, Banten, through product innovation analysis, Market Orientation, and Entrepreneurship orientation towards the MSME marketing performance of cassava processed products in the Lebak-Banten region. The research method used was a mixed-method, with a population of SMEs processed by cassava in the Cibadak area, Lebak, Banten. The number of respondents used was 72 respondents. Product innovation and entrepreneurial orientation do not affect marketing performance, but market orientation has significantly related to marketing performance. The MSMEs in Lebak Banten are not supported by inappropriate information technology. In this case, it is to improve the entrepreneurial orientation of the MSME actors by displaying all products that are sold either the same or not the same as the intended product so that consumers walk on their own to see the uniqueness said indirectly.
\end{abstract}

\section{Keywords:}

Product Innovation, Market Orientation, Entrepreneurship Orientation, Marketing Performance, UMKM

\section{Corresponding Author:}

Miguna Astuti

Fakultas Ekonomi dan Bisnis, Universitas Pembangunan

Nasional Veteran Jakarta. Email: miguna.astuti@upnvj.ac.id

(c) The Author(s) 2021

DOI: https:/ / doi.org/ 10.36407/jmsab.v4i1.276
Received: 01 Feb 2021

Accepted: 10 Jun 2021

Online: 25 Jul 2021

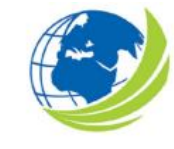

Jurnal Manajemen Strategi dan Aplikasi Bisnis, Vol 4, No. 2, 2021, pp. 331 - 342 eISSN 2655-237X

\section{(c)}

CC BY: This license allows reusers to distribute, remix, adapt, and build upon the material in any medium or format, so long as attribution is given to the creator. The license allows for commercial use. 


\section{PENDAHULUAN}

Kelompok usaha ultramikro yang secara konteks berada di bawah usaha mikro sendiri belum terdefinisikan dalam Undang-Undang No. 20 tahun 2018, namun jumlahnya dinyatakan cukup signifikan dalam perekonomian Indonesia dan perlu mendapatkan perhatian yang serius (Simanjuntak, 2019). Selanjutnya, Dinkop dan UKM Lebak mengemukakan bahwa persentase usaha mikro, kecil dan menengah yaitu 98,74\%, 1,24\% dan 0,02\% (Anonymous, 2019). Sehingga jumlah pelaku usaha usaha ultramikro masih mendominasi yaitu sebanyak 36.157. Hal tersebut mengindikasikan bahwa Lebak sebagai salah satu kabupaten dengan wilayah terbesar di Provinsi Banten belum mengembangkan sumber daya alam dan manusia lokal-nya yang tinggi secara optimal.

Data Dinas Koperasi dan UKM Pemerintah Propinsi Banten menyatakan bahwa pelaku UMKM di wilayah Lebak lebih dari 50 ribu. Diantaranya mereka bergerak di bidang usaha industri kerajinan kayu, logam, kulit dan usaha rumahan serta aneka jenis makanan (home industry). (Bantenantarnews, 2018). Pelaku usaha berskala mikro didalamnya terdiri atas usaha ultramikro dengan persentase mencapai angka 72,1\% (Brata, 2019).

Salah satu sumber daya potensial di wilayah Lebak bersumber dari bidang pertanian. Namun data Dinas Pertanian dan Perkebunan Kabupaten Lebak menyatakan bahwa produktivitas dari tanaman pangan unggulan di wilayah ini masih tergolong rendah. Termasuk pula pada rendahnya produktivitas tanaman Singkong yang masih jauh di bawah angka ideal karena hanya mencapai 20,9 juta ton per hektar (Nurani, 2018). Data Dinas Koperasi dan UKM menyatakan hal tersebut menyebabkan jumlah UMKM meningkat dari tahun ke tahun, namun persentase dari skala usaha ultramikro, mikro, kecil dan menengah di wilayah Lebak tidak mengalami perubahan yang signifikan.

Uraian di atas mengindikasikan adanya permasalahan kinerja pemasaran dimana pendapatan UMKM sebagai salah satu indikator kinerja pemasaran terindikasi stagnan, sehingga persentase skala usaha di wilayah tersebut tidak mengalami perubahan yang berarti. Komponen pemasaran tersebut merupakan hal vital yang perlu dilakukan dan dimiliki oleh suatu usaha yang bergelut dalam masyarakat kontemporer sebab masingmasing usaha yang berbeda beroperasi pada lingkungan yang sarat akan kompetisi . Indikasi tersebut diperkuat pula oleh data pendapatan dari 86 pelaku UMKM produk olahan singkong di wilayah Lebak, Banten seperti tergambar sebagai berikut.

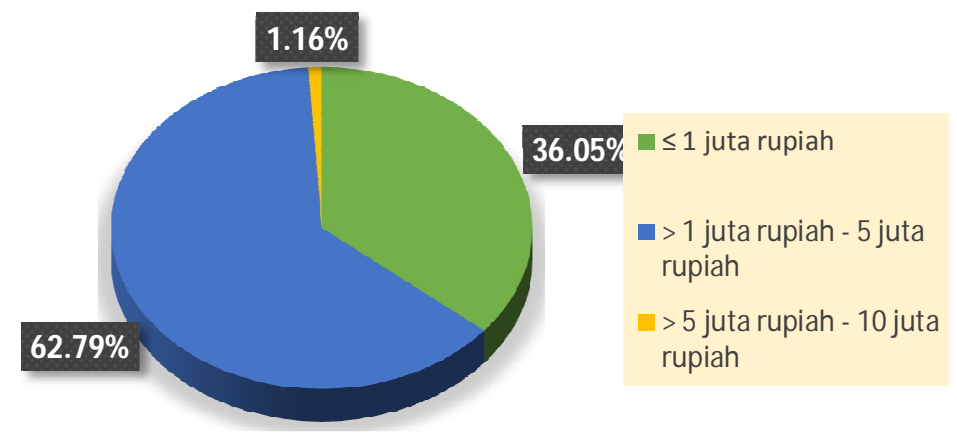

Sumber: Data diolah 2019

\section{Gambar 1.}

Pendapatan Pelaku UMKM Produk Olahan Singkong 


\section{Iskandar Budiman et al.}

Financial literacy, regrets experienced, excessive confidence, investment decisions

Berdasarkan gambar di atas, terlihat bahwa hanya 1,16\% pelaku UMKM yang memiliki pendapatan di antara 5 juta hingga 10 juta. Dengan asumsi bahwa jika pendapatannya rendah maka volume penjualannya juga rendah, maka data tersebut mendukung indikasi permasalahan kinerja pemasaran pada pelaku UMKM produk olahan Singkong di wilayah Cibadak, Lebak, Banten.

Kinerja pemasaran secara konteks dapat dicapai dengan memahami berbagai aktifitas baik yang bersifat finansial maupun nonfinansial . Aspek nonfinansial dari kinerja pemasaran tersebut dapat ditingkatkan melalui faktor Bauran Pemasaran dan, dimana bauran pemasaran tersebut merupakan salah satu komponen dari strategi pemasaran. Penelitian lain yang dilakukan dengan mengunakan metode uji regresi menyatakan pula bahwa bahwa orientasi pasar sebagai salah satu komponen dari strategi pemasaran secara signifikan dapat memberi pengaruh pada kinerja pemasaran . Hasil serupa juga dinyatakan oleh penelitian lain .Meski demikian, pada penelitian ini lebih lanjut dinyatakan bahwa melalui lingkungan persaingan, secara keseluruhan orientasi pasar tidak terbukti dapat memberi pengaruh yang positif kepada kinerja pemasaran.

Selanjutnya, penelitian terkait kinerja pemasaran yang dilakukan pada usaha makanan olahan di Surakarta menggunakan SEM menyatakan bahwa meski orientasi pasar dan inovasi secara signifikan berpengaruh terhadap kinerja pemasaran, namun orientasi kewirausahaan terbukti tidak berpengaruh terhadap kinerja pemasaran (Rahmawati, dkk, 2019). Hasil penelitian ini berbeda dengan beberapa penelitian serupa dimana dinyatakan bahwa orientasi pasar dan orientasi kewirausahaan dapat secara signifikan mempengaruhi kinerja pemasaran, demikian pula dengan inovasi.

Berdasarkan uraian diatas terlihat indikasi permasalaha kinerja pemasaran pada UMKM produk olahan singkong, dan lebih lanjut terlihat pula adanya kesenjangan penelitian terdahulu terkait pengaruh orientasi kewirausahaan, orientasi pasar serta inovasi secara Bersama-sama terhadap kinerja pemasaran. Hal ini menjadi dasar dilaksanakannya penelitian ini. Adapun tujuan dari penelitian ini adalah untuk mengetahui serta menganalisis pengaruh dari orientasi kewirausahaan, orientasi pasar dan inovasi produk terhadap kinerja pemasaran.

Penelitian ini diharapkan dapat memberikan kontribusi bagi ilmu pengetahuan dalam bidang pemasaran, penelitian ini juga dapat dijadikan masukan bagi pemerintah kabupaten Lebak, serta pemerintah kecamatan Cibadak, Lebak - Banten untuk mengetahui kondisi terkini serta potensi bisnis UMKM diwilayah desa mekaragung. Secara spesifik penelitian diharapkan dapat bermanfaat bagi bisnis UMKM produk olahan Singkong di desa Mekaragung, Cibadak, Lebak - Banten yang selama ini belum terpetakan potensinya. Melalui penelitian ini diharapkan pula dapat mengundang lima unsur (akademisi lain, bisnis, komunitas, pemerintah serta media) untuk secara bersama meningkatkan status Desa tertinggal menjadi berkembang dan/ atau maju

\section{KAJIAN PUSTAKA}

Manajemen pemasaran adalah analisis, perencanaan, penerapan, dan pengendalian programprogram yang dirancang untuk menciptakan, membangun, dan mempertahankan pertukaran yang saling menguntungkan dengan pembeli sasaran dalam rangka mencapai tujuan organisasi. Pemasaran berupaya menarik konsumen dengan menjanjikan nilai yang unggul dan tetap mempertahankan konsumen lama dengan memberikan kepuasan. menurut 
Jurnal Manajemen Strategi dan Aplikasi Bisnis, Volume 4, Nomor. 2, 2021. 331-342

mengatakan "Pemasaran merupakan sebuah konsep ilmur dalam strategi bisnis yang bertujuan untuk mencapai kepuasanr berkelanjutan bagi pelanggan, karyawanr dan pemegang saham. Kinerja pemasaran sendiri didefinisikan (Sudaryon, 2014) "kinerja dapat didefinisikan sebagian tingkat keberhasilan didalam melaksanakan tugas serta kemampun untuk mencapai tujuan yang telah di tetapkan". Sedangkan menurut (Sampurno, 2010) "kinerja pemasaran merupakan sebuah akumulasi dari hasil akhir dari sebuah proses dan aktivitas kerja dari perusahaan atau merupakan sebuahrtampilan keadaan secara utuhratas perusahaan selama periode waktu tertentu". Menurut "kinerja pemasaran dapat diukur dengan menggunakan pangsa pasar, tingkat kehilangan pelanggan, kepuasan pelanggan dan kualitas produk".

Orientasi Kewirausahaan didefinisikan "...semangat, perilaku, dan kemampuan untuk memberikan tanggapan yang positif untuk pelayanan yang lebih baik kepada pelanggan, dengan selalu menciptakan dan menyediakan produk yang lebih bermanfaat dan menerapkan cara kerja yang efisien melalui keberanian mengambil resiko, kreativitas, dan inovasi, serta kemampuan manajemen. Sedangkan orientasi kewirausahaan adalah sesuatu yang dapat meningkatkan inovasi yang agresif, memperbanyak proyek-proyek beresiko, dan cenderung menjadikan perusahaan sebagai pelopor inovasi yang dapat mencegah terjadinya persaingan (Wahyudi, 2012). Dengan kata lain, orientasi kewirausahaan merupakan sekumpulan proses yang digunakan entrepreneur untuk menstimulasi terjadinya keinovatifan, pengambilan resiko, dan keproaktifan. Selanjutnya orientasi kewirausahaan didefinisikan pula sebagai suatu proses, praktik dan kegiatan pengambilan keputusan yang dapat mengarahkan perusahaan untuk memasuki pasar baru atau meluncurkan produk baru (Friedricsen \& Benninghaus, 2013).

Orientasi pasar didefinisikan sebagai budaya organisasi yang menempatkan konsumen sebagai bagian yang utama dalam merencanakan bisnisnyamenurut Darmanto dan Kuntoro (2016, hlm. 43). Lebih lanjut, menurut Darmanto dan Kuntono (2016, hlm. 44) orientasi pasar merupakansesuatu yang penting bagi keberlangsungan perusahaan, sejalan dengan meningkatnya persaingan global dan perubahan dalam kebutuhan pelanggan dimana perusahaan menyadari bahwa mereka harus selalu dekat dengan pasar atau konsumennya. Lebih lanjut, Menurut menyatakan bahwa orientasi pasar merupakan ukuran perilaku dan aktivitas yang mencerminkan implementasi konsep pemasaran. Selanjutnya, masih menurut mendefinisikan orientasi pasar sebagai budaya bisnis yang mampu secara efektif dan efisien menciptakan perilaku karyawan sedemikian rupa sehingga menunjang upaya penciptaan nilai superior bagi para pelanggan .Lebih lanjut, menurut Tjiptono \& Chandra (2012), juga menyatakan bahwa orientasi pasar berpotensi dapat meningkatkan kinerja bisnis. Hal ini didukung oleh penelitian sebelumnya (Harini \& Yulianeu, 2019)

Inovasi merupakan sumber kesuksesan kompetitif, terutama di lingkungan yang bergolak dan sangat kompetitif. Dalam ekonomi kreatif, inovasi merupakan sarana untuk meningkatkan nilai tambah dan keunggulan bersaing. Menurut Robbins dan Coutler (2016) inovasi didefinisikan sebagai mengambil ide-ide kreatif dan mengubahnya menjadi produk atau metode kerja yang berguna. Menurut Jones (2010) inovasi adalah proses dimana organisasi menggunakan keterampilan dan sumber daya mereka untuk mengembangkan barang atau jasa baru atau untuk mengembangkan sistem produksi dan operasi baru sehingga mereka dapat merespons pelanggan mereka dengan lebih baik. Adapun menurut Ancok (2012), inovasi disimpulkan yaitu suatu proses memikirkan dan 


\section{Iskandar Budiman et al.}

Financial literacy, regrets experienced, excessive confidence, investment decisions

mengimplementasikan pemikiran tersebut, sehingga menghasilkan hal baru berbentuk produk, jasa, proses bisnis, cara baru, kebijakan, dan lain sebagainya. Adapun menurut Slamet (2014) inovasi adalah kemampuan untuk mengimplementasi ide-ide kreatif tersebut terhadap permasalahan dan peluang yang ada untuk meningkatkan dan memperkaya kehidupan seseorang. Hal ini didukung oleh penelitian sebelumnya (Risal \& Salju, 2017; Djojobo \& Tawas, 2014; Nurtiah, 2016; Karinda et al., 2018; Tahir et al., 2018; Indah \& Irma, 2014; Sarjita, 2017; Sirait et al., 2015). Berdasarkan uraian diatas maka hipotesis yang diajukan adalah:

$\mathrm{H}_{1}$ : Orientasi Kewirausahaan Terhadap Kinerja Pemasaran Umkm Produk Olahan Singkong Di Wilayah Lebak-Banten

$\mathrm{H}_{2}$ : Orientasi Pasar Terhadap Kinerja Pemasaran Umkm Produk Olahan Singkong Di Wilayah Lebak-Banten

$\mathrm{H}_{3}$ : Inovasi Produk Terhadap Kinerja Pemasaran Umkm Produk Olahan Singkong Di Wilayah Lebak-Banten

\section{METODE PENELITIAN}

\section{Desain Penelitian}

Penelitian ini menggunakan teknik analis kuantitatif dan kualitatif yang fokus pada kondisi lapangan dan masyarakat. Pendekatan serta tehnik Analisa pada penelitian ini menggunakan pendekatan rasionalistik dengan memperhatikan terlebih dahulu hal-hal umum menuju ke hal khusus sebagai dasar analisa suatu masalah. Jenis penelitian yang digunakan adalah mixed method, yaitu kualitatif dan kuantitatif. Sesuai wilayah penelitian, yaitu Kec. Cibadak. Teknik penelitian kuantitatif menekankan pada aspek pengukuran secara obyektif terhadap fenomena sosial

\section{Populasi dan Sampel}

Dalam pengambilan sampel peneliti menggunakan purposive sampling dengan kriteria yaitu yang berkepentingan dan bisa mewakili kelompok masyarakat di desa Mekaragung. Populasi dari penelitian ini adalah pelaku usaha produk olahan singkong terkait di desa Mekaragung. Pada penyebaran kuisioner ini sedang diberlakukannya pembatasan sosial berskala besar (PSBB) sehingga tim peneliti melakukan penyebaran kuisioner melalui googleform, dengan adanya keterbatasan waktu responden sehingga sampel yang diterkumpul hanya 72 responden.

\section{Variabel Operasional}

Untuk dapat melakukan pengukuran, setiap fenomena sosial di jabarkan kedalam beberapa komponen masalah, variabel dan indikator. Sedang secara kualitatif, dapat diperoleh gambaran dari masing-masing komponen masalah, variabel dan indikator tersebut. Adapun masing-masing variabel beserta indikator dapat dilihat pada tabel berikut:

Tabel 1.

Variabel Operasional

\begin{tabular}{|c|c|c|c|}
\hline Variabel & Dimensi & Indikator & Skala \\
\hline \multirow[t]{3}{*}{ Kinerja Pemasaran } & & - Kemampuan labaan & Likert \\
\hline & & - Volume penjualan & Likert \\
\hline & & - $\quad$ Pertumbuhan pelanggan & Likert \\
\hline
\end{tabular}


Jurnal Manajemen Strategi dan Aplikasi Bisnis, Volume 4, Nomor. 2, 2021. 331-342

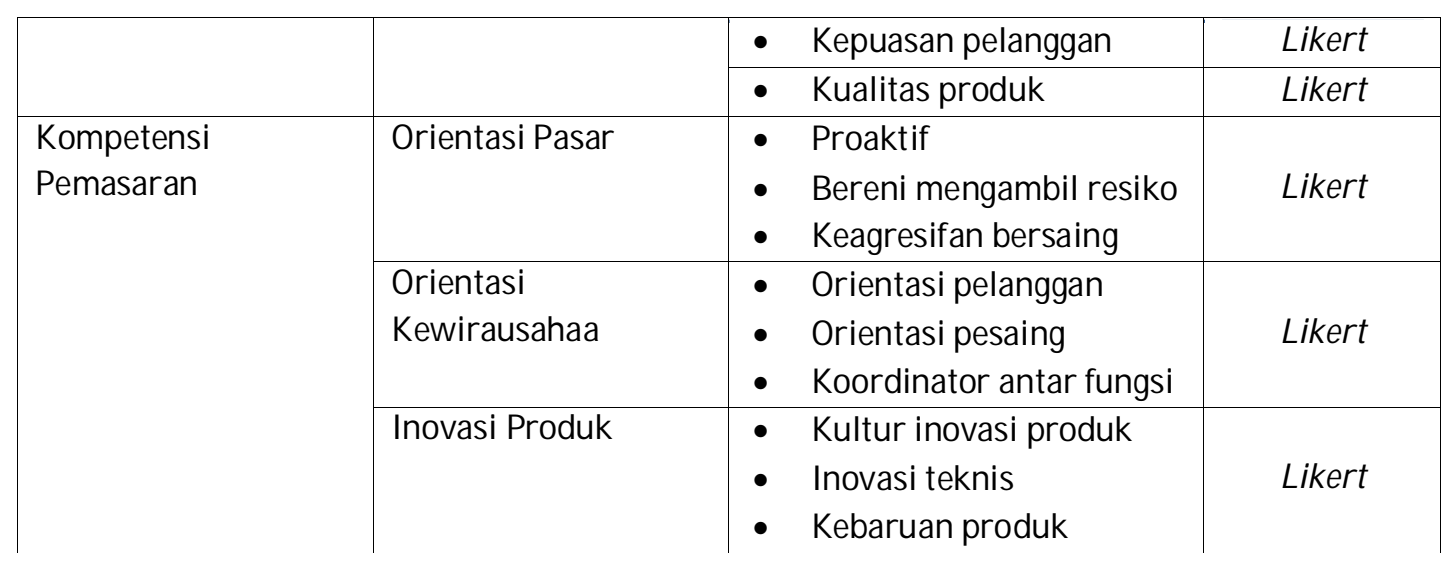

\section{HASIL DAN PEMBAHASAN}

\section{Deskripsi data}

Pada Sub bab ini akan dibahas gambaran data identitas usaha dan identitas responden UMKM produk olahan singkong di wilayah Lebak-Banten.

Identitas Usaha Berdasarkan Jenis Usaha

Responden dalam penelitian ini dikelompokkan menjadi beberapa lokasi di wilayah Lebak Banten. Responden yang dituju adalah Pemilik UMKM produk olahan singkong. UMKM produk olahan singkong di wilayah Lebak-Banten lebih banyak yang memiliki usaha jenis Kuliner yaitu sebesar 100\% atau sebesar 72 responden. Hal ini disebabkan karna usaha kuliner lebih mudah dalam proses penjualannya dengan cepat dibandingkan usaha non kuliner, usaha produk olahan singkong non kulier salah satu pelaku usaha membuat kantong plastik yang berasal dari kulit singkong.

\section{Identitas Usaha Berdasarkan Jenis Kuliner}

Responden dalam penelitian ini dikelompokkan menjadi beberapa lokasi di wilayah Lebak Banten. Responden yang dituju adalah Pemilik UMKM produk olahan singkong. UMKM produk olahan singkong di wilayah Lebak-Banten lebih banyak yang memiliki usaha jenis Kuliner makanan ringan yaitu sebesar $74 \%$ atau sebesar 53 responden dari 72 responden dibandingkan dengan usaha kuliner makanan beraat hanya 26\% atau 19 responden. Hal ini disebabkan karna usaha kuliner makanan ringan lebih banyak digemari diberbagai kalangan dan dalam penjualannya lebih murah dan lebih mudah dibawa kemana-mana sehingga dapat juga dijadikan sebagai oleh-oleh dengan ketahanan produk tahan lama. Usaha makanan ringan yang dijalankan rata-rata keripik singkong, opak dan lainnya. Sedangkan usaha makanan berat yaitu getuk, timus dan lainnya.

Identitas Usaha Berdasarkan Jumlah Pekerja atau Pegawai

UMKM produk olahan singkong di wilayah Lebak-Banten berdasarkan jumlah pekerja atau pegawai didominasi $<3$ orang memiliki persentase 89\% atai 64 responden. Hal ini disebabkan banyaknya yang memiliki usaha perorangan. Kemudian disusul memiliki pegawai 


\section{Iskandar Budiman et al.}

Financial literacy, regrets experienced, excessive confidence, investment decisions

3-5 orang memiliki persentase $7 \%$ atau 5 responden, 5-10 orang memiliki persentase 1\% atau 1 responden, 10-25 orang memiliki persentase 3\% atau 2 responden.

Identitas Usaha Berdasarkan Pendapatan Perbulan

UMKM produk olahan singkong di wilayah Lebak-Banten, pendapatan $<1$ Juta sebesar 13\% atau 47 Respondem, 1-5 Juta perbulan memiliki persentase sebesar 8\% atau 9 responden, 510 Juta perbulan memiliki persentase sebesar $6 \%$ atau 6 responden, 10-20 juta dan 20-50 juta perbulan memiliki persentase sebesar $8 \%$ atau 5 responden.

Identitas Responden Berdasarkan Jenis Kelamin

UKM produk olahan singkong di wilayah Lebak banten lebih banyak responden yang berjenis kelamin Wanita yaitu sebesar 58\% atau sebesar 42 dari 72 Responden dibandingan responden yang berjenis kelamin pria yaitu sebesar $42 \%$ atau 58 dari 72 responden.

Identitas Responden Berdasarkan Usia

Jumlah responden berdasarkan tingkatan usia dikelompokan menjadi 4 kategori yaitu: usia 17-25 tahun sebanyak 8 orang (11\%), usia 26-35 tahun sebanyak 18 orang (25\%), usia 36-45 tahun sebanyak 36 orang (50\%) dan usia $>45$ tahun sebanyak 10 orang (14\%). Sehingga responden yang berusia 36-45 tahun lebih mendominasi pada wilayah Lebak-Banten dalam hal responden UMKM produk olahan singkong.

Identitas Responden Berdasarkan Pendidikan Akhir

Responden berdasarkan tingkatan usia dikelompokan menjadi 6 kategori yaitu: Sd sebanyak 8\% atau 6 responden, SMP sebanyak 40\% atau 29 responden, SMA/ SLTA/ SMK sebanyak 25\% atau 18 responden, Diploma sebanyak 17 responden (24\%), Sarjana sebanyak 2 responden (3\%) dan Pascasarjana tidak ada pelaku usaha produk olahan singkong yang tidak ada dalam kategori tersebut. Persentase tertinggi yaitu pada kategori SMA/ SLTA/ SMK yang dimana lebih memilih untuk berwirausaha dibandingkan bekerja merantau.

\section{Analisis PLSdan Pembahasan}

Setelah melewati hasil statistic deskriptif, tahap selanjutnya pengujuan validitas dan reliabilitad pada penelitian ini hingga penelitian ini dinyatakan valid dan reliabel makan peneliti melanjutkan ke tahap berikutnya yaitu tahap uji hipotesis. Pada table 2 berikut akan disajikan hasil perhitungan Kinerja Pemasaran Umkm Produk Olahan Singkong Di Wilayah Lebak-Banten uji hipotesis yang diperoleh melalui output PLS.

Tabel 2.

Hasil Uji Hipotesis

\begin{tabular}{l|c|c|c|}
\hline & Oroginal Sample & T Statistics & P Values \\
\hline Inovasi Produk -> Kinerja Pemasaran & -0.025 & 0.495 & 0.621 \\
\hline Orientasi Kewirausahaan -> Kinerja Pemasaran & 0.021 & 0.440 & 0.660 \\
\hline Orientasi Pasar - > Kinerja Pemasaran & 0.969 & 29.811 & 0.000 \\
\hline
\end{tabular}


Jurnal Manajemen Strategi dan Aplikasi Bisnis,

Volume 4, Nomor. 2, 2021. 331-342

\section{Orientasi Kewirausahaan Terhadap Kinerja Pemasaran UMKM Produk Olahan Singkong Di Wilayah Lebak-Banten}

Berdasarkan hasil penelitian ini bahwa hasil pengujian hipotesis menunjukkan orientasi kewirausahaan tidak berpengaruh terhadap kinerja pemasaran. Hal ini ditunjukkan dengan nilai koefisien sebesar 0.021 dan menunjukkan nilai $t_{\text {hitung }} 0.440<t_{\text {tabel }} 1,996$ dan nilai $P$ Value sebesar 0,660 >0,05. Sehingga dapat diambil kesimpulan bahwa orientasi kewirausahaan tidak berpengaruh signifikan terhadap kinerja pemasaran atau dengan kata lain H1 ditolak.

Hal tersebut dapat dibuktikan dengan beberapa pernyataan yang tidak memberikan pengaruh yang kuat untuk orientasi kewirausahaan yaitu berani mengambil resiko menerima pesanan produk makanan yang berbeda dari apa yang saya jual dan berani mengambil resiko menerima pesan online. Hasil relevan ini dengan kondisi UMKM di Lebak Banten dimana memiliki usaha lainnya diluar produk yang biasanya mereka jual serta berani dalam penerimaan pesaan online yang tidak didukung dengan teknologi informasi yang tidak tepat. Dalam hal ini untuk meningkatkan orientasi kewirausahaan para pelaku UMKM dengan menampilkan semua produk yang dijual baik sama maupu tidak sama dengan produk yang dituju agar konsumen berjalan sendiri melihat keunikan yang ditampilkan secara tidak langsung.

Dapat diartikan bahwa pelaku UMKM kuliner di wilayah Lebak Banten Selatan kurang menyadari pentingnya orientasi kewirausahaan dalam meningkatkan kinerja pemasaran. Jika dilihat dari indikator-indikator orientasi kewirausahaan yaitu: inovatif, proaktif dan berani mengambil resiko tidak mampu memberikan pengaruh terhadap peningkatan kinerja pemasaran. Hal tersebut dikarenakan penerapan unsur-unsur orientasi kewirausahaan belum dilakukan sama sekali ataupun secara menyeluruh oleh pengelola usaha makanan dan minuman, karena keberadaan UMKM kuliner makanan Lebak Banten yang kebanyakan masih tradisional. Pelaku UMKM kuliner makanan dan minuman belum sepenuhnya memahami bagaimana cara menggunakan tahap atau proses orientasi kewirausahaan maka tidak terdapat perubahan yang berarti dibandingkan kompetitor. Kebanyakan pelaku UMKM kuliner makanan dan minuman di Lebak Banten turun langsung dalam menjalankan usahanya karena kurang mempercayai bahwa usahanya akan dijalankan dengan jujur dan berhasil jika ditangan orang lain.

Hasil penelitian ini sejalan dengan Hatta (2015); Priatin et al. (2017) dalam penelitiannya menyatakan bahwa orientasi kewirausahaan tidak berpengaruh terhadap kinerja pemasaran, kurangnya pemahaman usaha mengenai pengetahuan orientasi kewirausahaan, maka pengelola makanan perlu mengembangkan pemahaman pengetahuan orientasi kewirausahaan baik melalui ide-ide baru, tindakan berani mengambil resiko, percaya diri dan berfikir kedepan, pemahaman pengetahuan tersebut harus diarahkan pada peraktek nyata. Namun tidak sejalan dengan penelitian yang dilakukan oleh Yeni dkk (2014); Fatmawati (2016);Ibrahim et.al (2016) dalam penelitiannya menyatakan bahwa orientasi kewirausahaan berpengaruh terhadap kinerja pemasaran.

\section{Orientasi Pasar Terhadap Kinerja Pemasaran UMKM Produk Olahan Singkong Di Wilayah Lebak-Banten}

Berdasarkan hasil penelitian ini bahwa hasil menunjukkan orientasi pasar berpengaruh terhadap kinerja pemasaran. Hal ini ditunjukkan dengan nilai koefisien sebesar 0.969 dan 
Iskandar Budiman et al.

Financial literacy, regrets experienced, excessive confidence, investment decisions

menunjukkan nilai $t_{\text {hitung }} 29.811>t_{\text {tabel }} 1,996$ dan nilai P Value sebesar 0,000 <0,05.. sehingga dapat diambil kesimpulan bahwa orientasi pasar berpengaruh signifikan terhadap kinerja pemasaran atau dengan kata lain $\mathrm{H} 2$ diterima.

Hal tersebut dapat dibuktikan dengan beberapa pernyataan yang memberikan pengaruh yang kuat untuk orientasi pasar yaitu menggunakan metode pengolahan produk makanan yang berbeda (lebih baik) dari pada pesaing, terbuka kepada pegawai/partner (misal; tentang harga, promosi, jika mengeluarkan produk baru) dan memberikan penawaran khusus bagi pembeli/pelanggan (misal; diskon saat ulang tahun, bonus dalam pembelian partai besar). Hasil relevan ini dengan kondisi UMKM di Lebak Banten dimana dengan mempertahankan orientasi pasar seperti ini maka akan meningkatkan kinerja pemasarannya.

Dapat diartikan bahwa pelaku UMKM diwilayah Lebak Banten menyadari pentingnya orientasi pasar dalam meningkatkan kinerja pemasaran. Lebih lanjut, dapat diartikan pula bahwa rata-rata responden dalam penelitian ini memberikan tanggapan setuju dalam penentuan dan mempertimbangkan faktor orientasi pasar, yaitu orientasi pelanggan dan orientasi pesaing dengan indikatornya. Orientasi pasar mencerminkan kemampuan pelaku UMKM dalam memahami pelanggan oleh karena itu mempunyai peluang memberikan kepuasan kepada pelanggan, begitu pula dengan kemampuan orientasi pasar dalam mengenali gerak gerik pesaingnya. Besarnya kontribusi orientasi pasar pada UMKM kuliner

Sejalan dengan hasil penelitian ini, penelitian yang dilakukan olehFatmawati (2016) menyatakan bahwa dalam penelitiannya orientasi pasar memiliki pengaruh signifikan terhadap kinerja pemasaran. Hasil ini memberikan makna bahwa perusahaan yang memiliki tingkat orientasi pasar yang tinggi akan memiliki kinerja pemasaran yang tinggi. Selanjutnya penelitian yang dilakukan Sarjita (2017) dalam penelitiannya menyatakan jika orientasi pasar baik maka akan berpengaruh terhadap peningkatan kinerja pemasaran, sebaliknya jika orientasi pasar kurang baik, maka kinerja pemasaran menurun. Orientasi pasar merupakan budaya organisasi yang efektif dan efisien untuk menciptakan perilaku yang dibutuhkan perusahaan menuju superior performance bagi perusahaan. Lebih lanjut, penelitian yang di lakukan oleh Guspul (2016) menyatakan pula bahwa pengusaha yang berorientasi untuk memperluas jangkauan pemasaran akan merencanakan kinerja pemasaran dengan baik. Orientasi pasar pemilik atau pengelola usaha memberikan dampak terhadap meningkatnya kinerja UMKM, sebuah usaha yang berorientasi pasar meningkat, maka akan meiningkat juga kinerja pasarnya Yeni dkk, (2014).

\section{Inovasi Produk Terhadap Kinerja Pemasaran UMKM Produk Olahan Singkong Di Wilayah Lebak-Banten}

Berdasarkan hasil penelitian ini menunjukkan bahwa inovasi produk tidak berpengaruh terhadap kinerja pemasaran. Hal ini ditunjukkan dnegan nilai koefisien sebesar 0.025 dan menunjukkan nilai $t_{\text {hitung }} 0.495<t_{\text {tabel }} 1,996$ dan nilai P Value sebesar 0,621 >0,05. Sehingga dapat diambil kesimpulan bahwa inovasi produk tidak berpengaruh terhadap kinerja pemasaran atau dengan kata lain H3 ditolak.

Hal tersebut dapat dibuktikan dengan beberapa pernyataan yang tidak memberikan pengaruh yang kuat untuk inovasi produk yaitu mengolah produk dengan metode baru dan Kemasaan yang dibuat bervariasi sesuai variasi-variasi produk makanan yang ada. Hasil ini relevan dengan kondisi UMKM di Lebak Banten yang dimana memiliki metode baru yang tidak sesuai dengan makanan yang hendak dibuat atau makanannya tidak seenak dengan metode tradisional dalam proses pembuatannya serta kemasan yang dibuat tidak pasti atau 
tidak paten dengan ini maka akan membuang biaya yang tidak terduga. Pengusaha merasa perlu untuk mengembangkan atau memperluas produknya untuk memenuhi kebutuhan konsumen dengan tetap memperhatikan selera atau keinginan konsumen, sehingga produk yang sudah laku dipasaran dapat dikembangakan lagi yang berdampak pada meningkatnya pangsa pasar. Hasil penelitian ini tidak sejalan dengan hasil penelitian yang dilakukan oleh Rita Indah \& Irma (2014), Sarjita (2017) dan Manuel Leonard Sirait, dkk (2015) yang menyatakan bahwa dalam penelitiannya terdapat pengaruh yang signifikan antara inovasi terhadap kinerja pemasaran. Hasil tersebut menyatakan bahwa semakin baik inovasi yang dimiliki oleh suatu bisnis maka pencapaian kinerja dari bisnis tersebut juga akan semakin baik.

\section{KESIMPULAN}

Berdasarkan hasil analisis dan pembahasan yang telah diuraikan pada bab- bab sebelumnya mengenai Analisis Kinerja Pemasaran Umkm Produk Olahan Singkong Di Wilayah LebakBanten serta pengujian yang telah dilakukan maka dapat disimpulkan bahwa Orientasi Kewirausahaan tidak berpengaruh terhadap kinerja pemasaran UMKM Produk Olahan Singkong Di Wilayah Lebak-Banten, Orientasi Pasar berpengaruh terhadap kinerja pemasaran UMKM Produk Olahan Singkong Di Wilayah Lebak-Banten dan Orientasi Inovasi Produk tidak berpengaruh terhadap kinerja pemasaran UMKM Produk Olahan Singkong Di Wilayah Lebak-Banten.

\section{Keterbatasan dan Agenda Penelitian Mendatang}

Keterbatasan dalam penelitian ini yaitu Objek penelitian terbatas pada komoditas singkong. Perluasan objek dari segi komoditas dengan penambahan komoditas unggul lainnya di Lebak-Banten mungkin akan memberikan pemahaman hasil yang lebih komprehensif terhadap varribel yang diuji. Serta dalam proses penyebaran kuisioner di masa pandemic Covid-19 bukanlah hal yang mudah untuk mendapatkannya dengan cepat. Maka peneliti melakukan penyebaran kuisioner via google from. Untuk penelitian yang akan data peneliti akan menggunakan variabel lain untuk melkaukan penelitian keterkaitan dengan UMKM.

\section{REFERENSI}

Adede, O. A., Kibera, F. N., \& Owino, J. O. (2017). Electronic Marketing Practices, Competitive Environment And Performance Of Telecommunications Companies In Kenya. British Journal Of Marketing Studies, 5(5), 60-67.

Adewale, G., Adesola, \& Oyewale. (2013). Impact Of Marketing Strategy On Business Performance A Study Of Selected Small And Medium Enterprises (Smes) In Oluyole Local Government, Ibadan, Nigeria. Iosr Journal Of Business And Management, 11(4), 59-66.

Al Hadid, A., \& Qaddomi, B. A. (2016). The Effect Of Marketing Strategy On Maximizing The Performance Of An Organization: Sustainable Competitive Advantage As A Mediate Variable: Empirical Study On Small And Medium Companies In Jordan. International Journal Of Aca demic Research In Business And Social Sciences, 6(4), 318-324.

Aristiyo, R., \& Murwatiningsih. (2017). Meningkatkan Kinerja Pemasaran Melalui Keunggulan Bersaing Dengan Orientasi Kewirausahaan, Orientasi Pasar, Dan Kemitraan. Management Analysis Journal, Vol 6 (1) (2017). 
Iskandar Budiman et al.

Financial literacy, regrets experienced, excessive confidence, investment decisions

Ferdinand, A. (2011). Metode Penelitian Manajemen. Semarang: Badan Penerbit Universitas Ponorogo.

Harini, C., \& Yulianeu. (2019). Meningkatkan Kinerja Pemasaran Umkm Kota Semarang. IkraithEkonomika, 59-66.

Hasan, A. (2013). Marketing Dan Kasus- Kasus Pilihan Jilid 1 Edisi Ke-12. Yogyakarta: Center For Academic Publishing Service.

Hidayah, A., \& Purnadi. (2017, Maret). Pengaruh Strategi Pemasaran Dan Orientasi Wirausaha Terhadap Kinerja Pemasaran Yang Dimoderasi Oleh Lingkungan Persaingan Pada Industri Batik Sokaraja, Kabupaten Banyumas. Seminar Nasional Riset Manajemen \& Bisnis 2017.

Karinda, M. V., Mananeke, L., \& Roring, F. (2018). Pengaruh Strategi Pemasaran Dan Inovasi Produk Terhadap Kinerja Pemasaran Produk Indihome Pt.Telkom Area Tomohon. Jurnal Emba, 1568 - 1577.

Kartawinata, B. R., \& Wardhana, A. (2013). Marketing Strategies And Their Impact On Marketing Performance Of Indonesian Ship Classification Society. International Journal Of Science And Research (Ijsr) , 4(2), 69-74.

Kotler, P., \& Keller, K. L. (2016). Manajemen Pemasaran. Jakarta: Erlangga.

Kotler, Philip; Keller, Kevin Lake;. (2012). Manajemen Pemasaran. Jakarta: Erlangga.

Mansyur. (2018, September 27). Pelaku Umkm Di Lebak Meningkat. Retrieved From Banten Antar News: Https:// Banten.Antaranews.Com/ Berita/ 31419/ Pelaku-Umkm-Di-Lebak-Meningkat

Merakati, I., Rusdarti, \& Wahyono. (2017). Pengaruh Orientasi Pasar,Inovasi, Orientansi Kewirausahaan Melalui Keunggulan Bersaing Terhadap Kinerja Pemasaran. Journal Of Economic Education, 6 (2), 114 - 123.

Negrut, M. L., \& Mihartescu, A. A. (2016). Market Study On Performance Of The Marketing Function In Small And Medium Enterprises In Romania. Procedia - Social And Behavioral Sciences 221, 119-125.

Rahmawati, S., Darsono, \& Setyowati, N. (2019). Faktor-Faktor Yang Mempengaruhi Kinerja Pemasaran Pada Usaha Mikro Kecil Dan Menengah Pangan Olahan Di Kota Surakarta. Jurnal Ekonomi Pertanian Dan Agribisnis (Jepa), 3(2), 325-335.

Risal, \& Salju. (2017). Pengaruh Bauran Pemasaran (4ps) Dalam Meningkatkan. Jurnal Balance, 15(1): 1-18.

Sudaryanto, Ragimun , \& Wijayanti, R. R. (2018). Strategi Pemberdayaan Umkm Menghadapi Pasar Bebas Asean. Jakarta.

Suherly. (2016). Marketing Performance As The Impact Of Marketing Mix Strategy (7p) With Determination Of Market Attraction And Company's Resources Survey On Performers Of Tourism Industry In Timor Leste. International Journal Of Economics, Commerce And Management, 4(9), 569-587.

Tambunan, Tulus. (2012). Usaha Mikro Kecil Dan Menengah Di Indonesia: Isu-Isu Penting. Jakarta: Lp3es.

Tjiptono, F. (2015). Strategi Pemasatan. Yogyakarta: Andi.

Tjiptono, Fandy. (2012). Strategi Pemasaran. Yogyakarta: Andi Offset.

Undang-Undang Ri No.20 Tahun 2008. (2008). Usaha Mikro Kecil Dan Menengah. Jakarta: Eko Jaya.

Wibowo. (2006). Manajemen Perubahan. Jakarta: Pt. Raja Grafindo Persada. 
Jurnal Manajemen Strategi dan Aplikasi Bisnis,

Volume 4, Nomor. 2, 2021. 331-342

\title{
Competing interests
}

The authors declare that they have no competing interests.

\section{Funding}

The authors received internal funding from Universitas Pembangunan Nasional Veteran Jakarta (UPNVJ) for the completion of this research

\begin{abstract}
About the Authors
Dr. Miguna Astuti, S.Si.,MM.,MOS.,CPM adalah dosen senior bidang pemasaran dan strategi pemasaran di Universitas Pembangunan Nasional Veteran Jakarta dengan pengalaman mengajar Kewirausahaan, Bisnis Internasional, Bisnis dan Keuangan Internasional, Manajemen Pemasaran, Manajemen Pemasaran internasional, Manajemen Pemasaran jasa, Metode Riset bisnis, Manajemen Stratejik, Perilaku Konsumen dan Komunikasi pemasaran, Manajemen Pemasaran Syariah, Perilaku Organisasi, Riset Pemasaran, Seminar Manajemen Pemasaran dan Ekonomi Manajerial di tingkat Pascasarjana. Penulis memiliki ketertarikan dalam penelitiannya termasuk strategi pemasaran dan perilaku konsumen. Penulis koresponden ini dapat dihubungi di email: miguna.astuti@upnvj.ac.id
\end{abstract}

Tati Handayani merupakan dosen pemasaran pada program studi Ekonomi Syariah, fakultas Ekonomi dan Bisnis di Universitas Pembangunan Nasional Veteran Jakarta. Tati menempuh studi pada S1 jurusan manajemen di Universitas Islam Jakarta dan S2 manajemen pemasaran di Universitas Persada Indonesia "YAI" Jakarta. Workshop yang pernah diikuti adalah Certified International Sales Management Associate(2016), Basic Understanding of Islamic Banking Training (2017) oleh Muamalat Institute, Pelatihan Islamic Finance (2017) oleh Ikatan Sarjana Ekonomi Indonesia dan Bank Rakyat Indonesia Syariah. Selain aktif mengajar, penulis juga aktif dalam penelitian dan penulisan karya ilmiah, diantaranya adalah (1) Strategi Pengembangan Pemasaran Beras Pada Gapoktan Tani Mulya, (2) Positioning In Selecting Private University in Jakarta, (3) Strategi Pemasaran Kerajinan Kulit Dengan Metode QSPM di Kecamatan Rangkasbitung Kabupaten Lebak-Banten, (4) Pengembangan Kawasan Wisata Syariah Melalui Optimalisasi Potensi Desa Mekar Agung Kecamatan Cibadak Kabupaten Lebak Banten.Buku yang sudah diterbitkan yaitu Buku Ajar Manajemen Pemasaran Islam, Positioning Bank Syariah di Jakarta dan Manajemen Pariwisata. Dapat dihubungi melalui e-mail: tatihandayani01@gmail.com. 